\title{
Management accounting
}

\author{
Anthony Cook
}

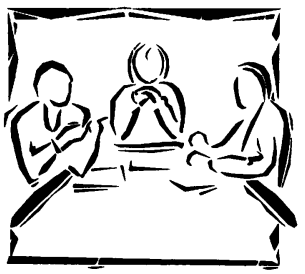

This is the seventh in a series of articles dealing with issues arising as clinical practitioners increasingly take on managerial roles. The series is edited by fenny Simpson
Department of Accounting and Finance, University of Birmingham, Birmingham B15 2RT

Anthony Cook, lecturer

BMF 1995;310:381-5
There is a distinction to be made between financial accounting and management accounting. Financial accounting is concerned with having sound financial systems in place to enable routine transactions-the payment of wages and salaries, the purchase of goods and services, the collection of income from customers, and so on-to take place; to maintain appropriate records; and to produce year end accounts. Management accounting, on the other hand, is concerned with producing financial information to assist the management of the organisation.

Back in 1978, a Royal Commission noted the almost complete absence of dynamic management accounting information in the NHS, ${ }^{1}$ so most financial developments during the 1980s were developments in management accounting. However, the government's reforms following the 1989 Working For Patients white paper have initially had an enormous impact on NHS financial accounting. In particular, the creation of the NHS trusts has been important in two respects. Firstly, they need their own finance departments-with all the appropriate systems-within the trust. Previously such systems were usually located within the district health authority. This has entailed a massive reorganisation of finance departments. Secondly, trusts are subject to a three point financial regime which affects their balance sheet, their income and expenditure account, and their funds flow statement. Now that the restructuring of the NHS is nearing completion (well, maybe) the pendulum is swinging back towards management accounting.

The Chartered Institute of Management Accountants Official Terminology defines management accounting as "an integral part of management concerned with identifying, presenting and interpreting information used for:

- Formulating strategy

- Planning and controlling activities

- Decision taking

- Optimising the use of resources."2

Such a definition requires that we are clear about the overall objectives of the organisation. Most private sector commercial organisations might define their financial objectives as "maximising their return on capital employed," but in the public sector the financial objective must be "to deliver value for money" from the resources provided. Furthermore, as a result of the work of the Public Accounts Committee and the National Audit Office, value for money can be expressed in terms of the three e's: economy, efficiency, and effectiveness. These terms can themselves be further defined, but for our purposes, the simplest definitions will suffice:

- Economy means "doing it cheaply"

- Efficiency means "doing it right"

- Effectiveness means "doing the right thing."

While many would argue that effectiveness is the most important, what value for money really requires is that we must deliver effective services and we must deliver them efficiently and economically.

Perhaps the main aspect in which management accounting differs from financial accounting is the time perspective. Whereas year end (financial) accounts are historical documents, management accounting is essentially forward looking. It involves making projections, preparing plans, and asking "what happens if?" And the type of questions to be addressed in management accounting would include:

- How much does it cost to deliver our services?

- How much does each activity cost?

- How much does it cost to treat patients in this particular category?

- Is it cheaper to contract out particular activities (such as catering, pathology, laboratories) or to provide them ourselves?

- Should we build an extension to our existing hospital or should we build a new hospital?

- When should we replace our motor vehicles?

- Should we replace the hospital boiler plant?

And crucially:

- How can we ensure that we live within our means?

These questions can therefore be one off, requiring ad hoc investigations and reports, or they can be on going, requiring some continuous form of reporting. And it is the latter-the process of ongoing financial planning, monitoring, and control-which forms the core of management accounting. This process is known as budgetary control.

\section{Budgetary control}

Budgetary control, or as it is more popularly known, budgeting, is usually an annual, cyclical process (although budgets can be prepared for longer or shorter periods). However, with a sound system of budgeting in place, the other management accounting activities-whether short term ad hoc investigations or longer term strategic plans-become much more straightforward and are built on secure foundations.

This is where budgetary systems enter the picture. A definition taken in part from an earlier (1960) management accounting terminology states: "Budgets are financial and/or quantitative statements, prepared and approved prior to a defined period of time, of the policy to be pursued during that period for the purposes of attaining given objectives."'3 Budgeting, in fact, is not just a financial exercise, but, as with management accounting in total, an integral part of management.

A useful starting point to understand budgeting in the NHS is the figure." This shows a "three level" analysis of expenditure. Firstly, money coming into the hospital can be analysed according to what (salaries for doctors, salaries for nurses, the purchase of drugs, etc) it has been spent on. Secondly, the "departmental" analysis shows "departments in which the expenditure has occurred." Thirdly, a "patient "care analysis" asks on what categories of patient care has the money been spent?

The first budgets to be introduced in the NHS followed the 1974 reorganisation (which created regional health authorities and area health authorities). These were referred to as functional budgets. These would actually be at the second level on the diagram but would represent budgets for each function 


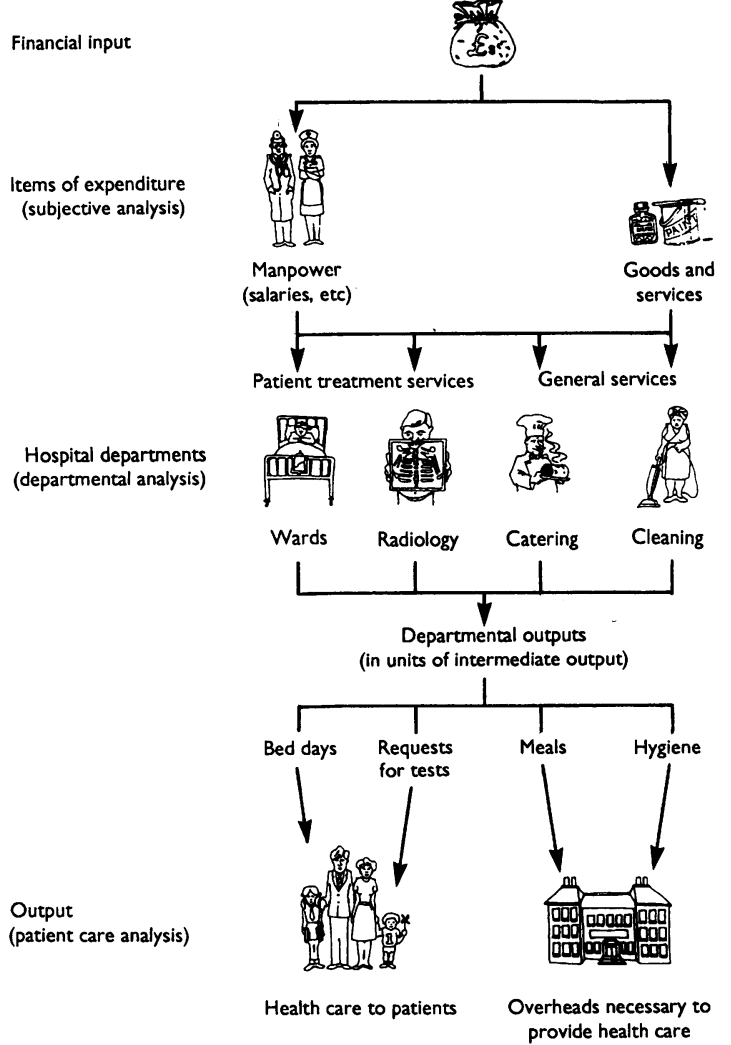

"Three level" analysis of expenditure." Examples from hospital departments show how money is used in a hospital day by day

(medical, nursing, pharmacy, etc) across a hospital site, or in some cases, across an area health authority. It soon became apparent that this was actually too near the top in the managerial hierarchy (particularly in respect of nursing) and if budgetary control was to be effective it should be devolved further down the managerial pyramid to individual departments. Hence the reference to departmental budgets.

According to Garbutt, there are three main stages in the budgetary process:

(1) Budget setting, in which budgets are set up for agreed responsibility levels in consultation with the responsible managers;

(2) Reporting, in which the staff for whom targets have been set are provided with information comparing actual performance with the budgets. Such compo-

TABLE I-Hypothetical departmental budgeting statement

Langlands Hospital NHS Trust

Budget report: Catering Department: September 1994

\begin{tabular}{|c|c|c|c|c|c|c|}
\hline & \multicolumn{3}{|c|}{ Year to date } \\
\hline & $\begin{array}{c}\text { Budget } \\
£\end{array}$ & $\stackrel{\text { actual }}{£}$ & $\begin{array}{l}\text { Variance } \\
£\end{array}$ & $\begin{array}{c}\text { Budget } \\
£\end{array}$ & $\underset{£}{\text { Actual }}$ & $\underset{£}{\text { Variance }}$ \\
\hline \multicolumn{7}{|l|}{ SALARIES AND WAGES } \\
\hline Catering manager & 2000 & 2000 & & 12000 & 12000 & \\
\hline Kitchen staff: Basic & 18000 & 16800 & -1200 & 108000 & 103157 & -4843 \\
\hline Overtime & & 975 & 975 & & 3063 & 3063 \\
\hline Canteen staff: Basic & 5750 & 6250 & 500 & 34500 & 37134 & 2634 \\
\hline Overtime & & 155 & 155 & & 907 & 907 \\
\hline SUBTOTAL & 25750 & 26180 & 430 & 154500 & 156261 & 1761 \\
\hline \multicolumn{7}{|l|}{ OTHER EXPENDITURE } \\
\hline Provisions & 60000 & 70497 & 10497 & 360000 & 395541 & 35541 \\
\hline Other supplies & 5500 & 4936 & -564 & 33000 & 28432 & -4568 \\
\hline Services & 7500 & 7705 & 205 & 45000 & 47156 & 2156 \\
\hline SUBTOTAL & 73000 & 83138 & 10138 & 438000 & 471129 & 33129 \\
\hline INCOME & -30000 & -25575 & 4425 & -180000 & -155676 & 24324 \\
\hline NET EXPENDITURE & 68750 & 83743 & 14993 & 412500 & 471714 & 59214 \\
\hline \multicolumn{7}{|l|}{ STAFF STATISTICS } \\
\hline Catering manager & 1 & 1 & & 1 & 1 & \\
\hline Kitchen staff & 30 & 28 & -2 & 30 & 29 & -1 \\
\hline Canteen staff & 10 & 11 & 1 & 10 & 11 & 1 \\
\hline TOTAL STAFF & 41 & 40 & -1 & 41 & 41 & \\
\hline \multicolumn{7}{|l|}{ MEALS SUPPLIED } \\
\hline Patients & 45000 & 47770 & 2770 & 270000 & 293317 & 23317 \\
\hline Staff & 15000 & 13532 & -1468 & 90000 & 79834 & -10166 \\
\hline TOTAL & 60000 & 61302 & 1302 & 360000 & 373151 & 13151 \\
\hline
\end{tabular}

sitions should lead to corrective action if necessary. (3) Reviewing, in which budgets may be revised if business conditions change during the current period, or as a starting point for the next period.

As in any other large organisation, these stages can and have been applied in NHS acute hospitals. Table I shows a hypothetical example of a departmental budgeting statement.

Indeed, if the only financial objective is the historical aim of living within the cash limit (the economy aspect of the three e's), then many NHS hospitals have been well served by departmental budgets.

Unfortunately, that is not the end of the story. Garbutt identifies six purposes served by budgets. They are used to

- Allocate resources

- Quantify plans

- Coordinate departmental activities

- Communicate management plans and objectives

- Set performance objectives and targets

- Plan and control business performance.

Departmental budgets certainly contribute to the first three purposes, but they are seriously deficient in achieving the last three. That is because in a hospital fundamental objectives need to be set in clinical terms. With departmental budgets, this is not possible.

Departmental budgets are also deficient in the control aspect, because it is clinical decisions taken (predominantly) by doctors which actually incur expenditure. For example, when doctors prescribe drugs for a patient they are actually making a financial decision, as well as a clinical one. Yet in a departmental system of budgeting the doctor is not held accountable -in financial terms - for that decision.

The corollary to that is that the departmental manager-in the NHS the chief pharmacist-is expected somehow to live within his departmental budget, although he has no control over what drugs he is required to dispense and in what quantities.

Hence something better than the departmental system of budgeting is required. This is achieved in the figure by moving down from level 2 (the departmental analysis of expenditure) to level 3 (described in the diagram as "the patient care analysis" but often referred to as the clinical analysis of expenditure).

Just as there are differing degrees of detail in thinking in terms of the subjective or departmental analysis of expenditure, so there are greater or lesser degrees of detail for the clinical analysis. Conventional wisdom has it that clinical expenditure can be analysed to five levels:

(1) Broad client group where we are talking in terms of "mental illness," "mental handicap," "maternity," etc.

(2) Clinical specialty-orthopaedics, paediatrics, general surgery, etc.

(3) Consultant to the clinical team of consultant and junior doctors.

(4) Disease category in which all patients with similar complaints, and due to be treated in a similar way, are grouped together.

(5) Individual patient-How much has it cost to treat Mr Jones or Mrs Smith?

Since the Royal Commission report of 1978 there have been separate initiatives concerned with analysing expenditure to each of these levels.

In fact, analysis to client group goes back to the early 1970 s and is referred to (misleadingly) as programme budgeting. The technique includes making broad brush assumptions about how costs can be allocated to each client group. There is nothing precise about the technique and the figures are of limited use as management information because they contain no information 


\begin{tabular}{|c|c|c|c|c|c|c|c|c|c|c|}
\hline \multirow[b]{3}{*}{ Specialties } & \multirow{3}{*}{$\begin{array}{l}\begin{array}{l}\text { Main } \\
\text { code }\end{array} \\
\text { Sub } \\
\text { code }\end{array}$} & \multicolumn{5}{|c|}{$\begin{array}{l}\text { Patients using a bed } \\
\text { (including day cases) }\end{array}$} & \multicolumn{4}{|c|}{$\begin{array}{l}\text { Outpatients } \\
\text { (including a nurse clinic and ward attenders) }\end{array}$} \\
\hline & & $\begin{array}{l}\text { Patient } \\
\text { days } \\
56\end{array}$ & $\begin{array}{l}\text { Consultant } \\
\text { GP } \\
\text { episodes } \\
57\end{array}$ & $\begin{array}{c}\text { Expenditure } \\
58\end{array}$ & $\begin{array}{l}\text { Cost per } \\
\text { patient } \\
\text { day } \\
59\end{array}$ & $\begin{array}{c}\text { Cost per } \\
\text { episode } \\
60\end{array}$ & $\begin{array}{c}\text { First } \\
\text { attendances } \\
61\end{array}$ & $\begin{array}{c}\text { Total } \\
\text { attendances } \\
62\end{array}$ & $\begin{array}{l}\text { Expenditure } \\
63\end{array}$ & $\begin{array}{c}\text { Cost per } \\
\text { attendance } \\
64\end{array}$ \\
\hline & & & & $£$ & $£$ & $£$ & & & $£$ & $£$ \\
\hline $\begin{array}{ll}\text { B } & \text { Surgical specialties } \\
\text { a } & \text { General surgery } \\
\text { b Urology } \\
\text { c Orthopaedics } \\
\text { d ENT } \\
\text { e Ophthalmology } \\
\text { f Gynaecology } \\
\text { g Dental specialties } \\
\text { h Neurosurgery } \\
\text { i Plastic surgery } \\
\text { j Cardiothoracic } \\
\text { k Pediatric surgery } \\
\text { Subtotal B }\end{array}$ & $\begin{array}{l}200 \\
201 \\
202 \\
203 \\
204 \\
205 \\
206 \\
207 \\
208 \\
209 \\
210 \\
299\end{array}$ & $\begin{array}{r}23194 \\
8231 \\
19289 \\
4926 \\
\\
10353 \\
618\end{array}$ & $\begin{array}{r}6363 \\
2596 \\
2203 \\
2684 \\
\\
5493 \\
519\end{array}$ & $\begin{array}{r}5216740 \\
1998665 \\
3350243 \\
1434346 \\
2312356 \\
274080\end{array}$ & $\begin{array}{c}224.92 \\
242.82 \\
1173.69 \\
291.18 \\
\\
223.35 \\
443.50\end{array}$ & $\begin{array}{r}819.86 \\
769.90 \\
1520.76 \\
651.09 \\
\\
420.96 \\
528.09\end{array}$ & $\begin{array}{l}4252 \\
2011 \\
3236 \\
5021 \\
2303 \\
2832 \\
1901\end{array}$ & $\begin{array}{r}13466 \\
5923 \\
13092 \\
11819 \\
8981 \\
8952 \\
7158\end{array}$ & $\begin{array}{l}293834 \\
188694 \\
577244 \\
504819 \\
318817 \\
276345 \\
409678\end{array}$ & $\begin{array}{l}21.82 \\
31.86 \\
44.09 \\
42.71 \\
35.50 \\
30.87 \\
57.23\end{array}$ \\
\hline $\begin{array}{l}\text { C Maternity function } \\
\text { a Obstetrics } \\
\text { b General practice } \\
\text { Subtotal C }\end{array}$ & $\begin{array}{l}301 \\
302 \\
399\end{array}$ & $\begin{array}{r}16291 \\
1271 \\
17562\end{array}$ & $\begin{array}{r}5093 \\
872 \\
5965\end{array}$ & $\begin{array}{r}3440795 \\
114682 \\
3555477\end{array}$ & $\begin{array}{r}21121 \\
90.23 \\
202.45\end{array}$ & $\begin{array}{l}675.59 \\
131.52 \\
596.06\end{array}$ & $\begin{array}{l}4120 \\
4120\end{array}$ & $\begin{array}{l}16051 \\
16051\end{array}$ & $\begin{array}{l}668995 \\
668995\end{array}$ & $\begin{array}{l}41.68 \\
41.68\end{array}$ \\
\hline $\begin{array}{l}\text { D Psychiatric specialties } \\
\text { a Mental handicap } \\
\text { b Mental illness } \\
\text { c Child and adolescent } \\
\text { psychiatry } \\
\text { d Forensic psychiatry } \\
\text { e Psychotherapy } \\
\text { f Old age psychiatry } \\
\text { Subtotal D }\end{array}$ & $\begin{array}{l}401 \\
402 \\
\\
403 \\
404 \\
405 \\
406 \\
499\end{array}$ & & & & & & 13 & 91 & 18390 & 202.09 \\
\hline Total B-D & 500 & 84173 & 25823 & 18141907 & 215.53 & 702.55 & 25728 & 85709 & 3264898 & 38.09 \\
\hline
\end{tabular}

as to whether the resources have been used efficiently or effectively. Accordingly, programme budget figures are perhaps of greater use at the public accountability level in giving an explanation to outsiders of the way NHS resources are displayed. Recent Department of Health reports have contained "pie chart" programme budget figures.

At the next level is specialty costing. Specialty costs are, by definition, calculations of historical average costs per case within each specialty. Usually they are produced at the end of each financial year, although they can be (and in some cases are) produced more frequently. The technique has been in existence for some years and health authorities (and now trusts) have been required to produce specialty cost returns since the 1987-8 financial year (table II). Used properly, specialty costing information can be useful for monitoring and questioning on a retrospective basis, or even planning and pricing on a prospective basis.

There have been several initiatives aimed at developing patient costing, which, of course, aims to calculate how much it has cost to treat each patient. Some early examples of patient costing were known as the financial information project. Now, of course, patient costs are required in the internal market for pricing extracontractual referrals (ECRs). However, for management accounting purposes, while costs can be analysed retrospectively to the individual patient, it is not possible to plan prospectively at this level-it is not possible to predict that $\mathrm{Mr}$ Jones will have a heart attack next October.

Thus these three techniques-programme budgeting, specialty costing, and patient costing-are certainly of value but do not overcome all the limitations of departmental budgets. Consequently, the real need in NHS management accounting is to develop systems of clinical budgeting.

There were two notable early initiatives designed to concentrate at level 3-the consultant-on the clinical axis. The first of these was CASPE, which stands for Clinical and Service Planning Evaluation, and which was actually a small research group based at the King's Fund, London. CASPE dated from 1979 and the early trials concentrated on the planning rather than the control aspects of clinical budgets. Hence discussions were held with consultants and agreements drawn up as to what would be the anticipated workload for the clinical team and what resources they would reasonably require to deliver that workload.

In 1983 the Griffiths report was published and management budgeting demonstration districts were established. A supporting paper written by J Blyth (unpublished) argued that the objective was:

to develop management budgets involving clinicians at unit level with the emphasis on management rather than accounting. The aim is to produce an unsophisticated system in which workload related budgets, covering financial and manpower allocations and full overhead costs, are closely related to workable service objectives against which performance and progress can be compared.

This is the key paragraph in a paper which logically argued the case for clinical budgets and established a number of basic principles. Generally those principles were soundly based, although one could argue against "full overhead costs," which do not follow what is generally regarded to be good industrial or commercial practice. Similarly, the paragraph gives a clue as to why management budgeting was officially deemed to have been a failure, in that it makes reference to an "unsophisticated system." The reality is that the development of clinical budgeting systems the world over has been anything but unsophisticated.

Table III shows how management budgeting overcame several of the technical problems in developing clinical budgets. But it identified several others: it identified the need to have better information systems, particularly in respect of patient administration, radiography, pharmacy, and pathology. It also identified a number of organisational and behavioural issuesin particular, what are the correct managerial relationships between the medical, nursing, and paramedical professions?

To what extent can clinicians be persuaded to accept that they are financially and managerially accountable for these decisions? And does this lead to a revision of the arrangements for incorporating clinicians into the managerial structure of the hospital? It was these issues which were deemed to have been 


\section{TABLE III-Management budgeting}

\begin{tabular}{|c|c|c|c|c|c|c|c|}
\hline \multicolumn{3}{|c|}{ Current month } & & \multirow[b]{2}{*}{ Expense codes } & \multicolumn{3}{|c|}{ Year to date } \\
\hline Budget & Actual & Variance & & & Budget & Actual & Variance \\
\hline 10998 & 10697 & -301 & 800 & $\begin{array}{l}\text { Staff costs controlled by team } \\
\text { Medical staff costs }\end{array}$ & 54990 & 53166 & -1024 \\
\hline $\begin{array}{r}12499 \\
290 \\
7697 \\
7283\end{array}$ & $\begin{array}{r}12014 \\
248 \\
9016 \\
7892\end{array}$ & $\begin{array}{r}-485 \\
-42 \\
1319 \\
609\end{array}$ & $\begin{array}{l}809 \\
811 \\
820 \\
821\end{array}$ & $\begin{array}{l}\text { Other expenses controlled by team } \\
\text { Prescribed drugs } \\
\text { Histopathology-consumables } \\
\text { Radiology-consumables } \\
\text { Operating theatre consumables }\end{array}$ & $\begin{array}{r}62495 \\
1450 \\
40837 \\
37415\end{array}$ & $\begin{array}{r}58712 \\
1193 \\
44808 \\
38878\end{array}$ & $\begin{array}{r}-3783 \\
-257 \\
3971 \\
2463\end{array}$ \\
\hline 38767 & 39867 & 1100 & & Total costs controlled by team & 197187 & 196757 & 570 \\
\hline $\begin{array}{r}4166 \\
83 \\
11572 \\
41 \\
1565 \\
833 \\
8208 \\
4107 \\
15485\end{array}$ & $\begin{array}{r}5152 \\
149 \\
10983 \\
193 \\
1782 \\
814 \\
7932 \\
4182 \\
15654\end{array}$ & $\begin{array}{r}986 \\
66 \\
-589 \\
152 \\
217 \\
-19 \\
-276 \\
75 \\
169\end{array}$ & $\begin{array}{l}840 \\
841 \\
845 \\
856 \\
849 \\
851 \\
861 \\
868 \\
880\end{array}$ & $\begin{array}{l}\text { Costs influenced by team } \\
\text { Ward-consumables } \\
\text { Outpatient-consumabfes } \\
\text { Ward—overheads } \\
\text { Outpatient-overheads } \\
\text { Pharmacy-overheads } \\
\text { Histopathology-overheads } \\
\text { Operating theatre-overheads } \\
\text { ECG—overheads } \\
\text { Physiotherapy - hydrotherapy }\end{array}$ & $\begin{array}{r}20830 \\
415 \\
57860 \\
205 \\
7825 \\
4165 \\
41040 \\
20535 \\
77425\end{array}$ & $\begin{array}{r}22584 \\
495 \\
58592 \\
452 \\
8571 \\
4046 \\
40643 \\
21916 \\
75296\end{array}$ & $\begin{array}{r}1754 \\
80 \\
732 \\
247 \\
746 \\
-119 \\
-397 \\
1381 \\
-2129\end{array}$ \\
\hline 46060 & 46841 & 781 & & Total costs influenced by team & 230300 & 232595 & 2295 \\
\hline $\begin{array}{r}2499 \\
973 \\
1219 \\
832 \\
7499\end{array}$ & $\begin{array}{r}2261 \\
1028 \\
817 \\
946 \\
6753\end{array}$ & $\begin{array}{r}-238 \\
55 \\
-402 \\
114 \\
-746\end{array}$ & $\begin{array}{l}890 \\
891 \\
892 \\
894 \\
896\end{array}$ & $\begin{array}{l}\text { General services overheads } \\
\text { Unit administration } \\
\text { Catering } \\
\text { Domestic } \\
\text { Linen-laundry } \\
\text { Estate management }\end{array}$ & $\begin{array}{r}12495 \\
4865 \\
6095 \\
4160 \\
37495\end{array}$ & $\begin{array}{r}11236 \\
5386 \\
3932 \\
4701 \\
35388\end{array}$ & $\begin{array}{rl}-1 & 259 \\
521 \\
-2163 \\
541 \\
-2107\end{array}$ \\
\hline 13022 & 11805 & -1217 & & Total general service overheads & 65110 & 60643 & -4467 \\
\hline 97849 & 98513 & 664 & & $\begin{array}{l}\text { Total costs for team } \\
\text { Memorandum statistics }\end{array}$ & 491597 & 489995 & -1602 \\
\hline $\begin{array}{l}857 \\
148 \\
499 \\
473 \\
599\end{array}$ & $\begin{array}{l}878 \\
193 \\
296 \\
682 \\
634\end{array}$ & $\begin{array}{r}21 \\
45 \\
-203 \\
209 \\
35\end{array}$ & $\begin{array}{l}900 \\
903 \\
914 \\
937 \\
940\end{array}$ & $\begin{array}{l}\text { Inpatients-days } \\
\text { Outpatients-attendances } \\
\text { Histopathology-tests } \\
\text { Radiology-tests } \\
\text { Operating theatre-hours }\end{array}$ & $\begin{array}{r}4285 \\
740 \\
2495 \\
2801 \\
2995\end{array}$ & $\begin{array}{r}4382 \\
849 \\
2650 \\
3690 \\
3286\end{array}$ & $\begin{array}{r}97 \\
109 \\
155 \\
889 \\
291\end{array}$ \\
\hline
\end{tabular}

Preliminary draft for a report, with simulated cost figures, reproduced from the CASPE Project at Lewisham and North Southwark Health Authority, by permission. Taken from Public Sector Accounting and Financial Control. ${ }^{6}$

inadequately addressed in the management budgeting initiatives.

Consequently, in 1986 "management budgeting" became resource management, in which greater attention was to be paid to the information systems and the organisational issues. However, from a management accounting point of view, the most important change to stem from resource management was the introduction of case mix planning and costing. Such an approach requires that patients with similar diseases and requiring similar treatment regimens should be grouped together. It is then possible to account for the complexity of cases handled rather than the simple numbers of patients treated. In the clinical analysis of expenditure this means moving down from level 3consultant-to level 4 -disease category. The development of case mix costing is perhaps the key area in the development of health care management accounting.

The accounting objective is to establish definable categories of patients, each of which can have defined treatment regimens, and then to build up defined treatment costs. Such an exercise involves setting standard costs for units of hospital activity, such as "occupied bed days" or "operating theatre hours," and then applying them to standard care profiles to produce, in management accounting terms, standard product costs. Most industrial or commercial concerns have standard costs for their product ranges and would regard them as essential information for financial planning, budgetary control, and pricing.

The difficulties arise, of course, from the fact that in the NHS we are dealing with patients in a hospital rather than products in a factory. Inevitably, therefore, even within the same category, some patients are more severely ill than others, some have more complications, some respond to treatment better than others, and so on. The real problem, therefore, with case mix costing is to identify groupings which make both medical sense-in that all patients in the group are clinically similar-and accounting sense-in that the treatment of each patient will require similar (and predictable) resources. The internal market creates a further requirement that case mix categories must make sense to purchasers-whether district health authorities or general practitioner fundholders.

\section{Defining categories of patients}

Thus the real issue is not the technicalities of the management accounting and information systems, but how to define the categories of patients. There have been several approaches to this.

For example, in the days of management budgeting Southmead developed early case mix costs for a small number of consultants. They were asked to identify the 10 or 12 case types which make up $80 \%$ or so of their routine workload. The defined treatment profile was then costed by using standard costs. This approach is perfectly logical on a local basis, but it makes comparisons between sites difficult.

The most well known system is that developed at Yale University in the United States and based on the International Classification of Diseases, whereby all acute patients can be allocated to one of 475 diagnosis related groups (DRGs). The Medicare system in the United States is actually funding hospitals on the basis of a price per DRG. In the United Kingdom the six original resource management sites initially started work with DRGs. However, more recently they have developed a system more suited to British practice and known as HRGs (health care resource groups). Table IV shows a hypothetical example based on recent British experience.

TABLE IV-Hypothetical example of classification according to health care resource graphs, based on British experience

Specialty: Orthopaedics

Procedure: Arthroplasty of hip

Average length of stay: 15 days

Theatre time: 1.83 hours

Estimated cost per case $(£)$

\begin{tabular}{lcrc} 
& Units & $\begin{array}{c}\text { Cost per } \\
\text { unit }\end{array}$ & $\begin{array}{c}\text { Cost } \\
\text { per case }\end{array}$ \\
\hline Preoperative nursing & $1 \cdot 00$ & 36.77 & 36.77 \\
$x$ Ray tests & $4 \cdot 20$ & 12.78 & 53.67 \\
Pathology laboratory & $6 \cdot 50$ & 11.75 & 76.37 \\
Theatre costs & $1 \cdot 83$ & 350.00 & 640.50 \\
Blood & $2 \cdot 46$ & 51.00 & 125.46 \\
Prosthesis & $1 \cdot 00$ & 545.00 & 545.00 \\
Drugs & $15 \cdot 00$ & 13.88 & 208.20 \\
Nursing & $15 \cdot 00$ & 37.00 & 555.00 \\
Other length of stay costs & $15 \cdot 00$ & 55.00 & 825.00 \\
Physiotherapy & $9 \cdot 50$ & 15.00 & 142.50 \\
\hline Total cost & & & 3208.47 \\
\hline
\end{tabular}

Another American approach stems from the Johns Hopkins University. This recognises that even within the same disease category, some patients are more seriously ill than others and require more extensive (and more expensive) treatment. This approach has therefore introduced severity ratings to enable patients to be classified into one of four categories of severity.

The reality is that case mix costing is still in its infancy and a precise system of classification has still to be developed. However, there is no reason to assume that the problems of classification will not eventually be overcome. But it will probably require more categories coupled with severity ratings. And this overall structure for the development of clinical budgeting with case mix costing was established well before the government embarked on the NHS reforms.

Now we have the "costing" for contracting initiative. This is guidance stemming from the NHS Executive to acute units on how they should classify costs and allocate or apportion overhead departments, etc, specifically for the purpose of calculating prices for the 
internal market. ${ }^{7}$ In fact, this addresses only one aspect and a comprehensive budgeting system can (and should) be used for planning, monitoring, and control purposes, in addition to pricing. Nevertheless, costing for contracting does follow the overall structure outlined above and it should be noted that, for the 1995-6 contracting round, trusts are required to price one of three specialties (orthopaedics, ophthalmology, or gynaecology) down to health resource group level. It will be interesting to see how many achieve that.

\section{Capital expenditure investment appraisal}

Undoubtedly, budgetary control is the core of management accounting in the NHS, just as it is in other large organisations. It provides the basis of short term financial control, ad hoc investigations, and strategic planning over a longer term. However, when plans are drawn up for a three, five, or 10 year perspective then there is a further management accounting technique that is equally important: capital expenditure investment appraisal. In financial accounting terms capital expenditure can be seen as expenditure of new fixed assets-land, buildings, equipment, etc. In economic terms, however, it can be seen as major items of expenditure incurred now, with a view to obtaining specific benefits in the futuremaybe several years in the future. The investment appraisal task, therefore, is to assess whether the anticipated benefits outweigh the cost being incurred now. There are two key aspects to this process in the NHS.

Firstly, it has to be recognised that the benefits (and to some extent the costs) are incurred at different times in the future. This means that they have different values to us now. Thus the promise of a payment of $£ 1000$ in a year's time is worth considerably more to us than the promise of $£ 1000$ in 10 years' time. The approach, therefore, is to assess the present value of benefits and costs which can be seen projecting forward into the future (up to 60 years in the future in the case of NHS building schemes). This involves a financial technique known as discounting, which basically involves using compound interest in reverse. The technique in the NHS is simply a variant of the technique known as discounted cash flow and which is widely used by management accountants in industry and commerce.

The second aspect of investment appraisal in the NHS, however, is that it is not possible to put a financial price on benefits achieved from better health care. It is not really possible to put a price on providing better care for elderly people or mentally handicapped people, or even for achieving better acute care. This is in contrast to the normal commercial world where a company can usually assess in financial terms (say, additional sales of a new product) the benefits anticipated from a capital expenditure scheme. Accordingly, in the NHS there is a developing process known as the appraisal of options. Under this approach the basic service need-say, to improve maternity services in a district-is identified in the strategic planning process. Once it is identified, the project team must then identify a number of alternative ways in which that service need can be met. These options could involve extending an existing hospital site, building a new hospital, or even improving community services (not all of the options have to be capital options). It then becomes possible to assess the financial costs of each option and the non-financial benefits and then to select the preferred option.

\section{Key point summary}

- Management accounting is concerned with producing financial information to assist the management of the organisation

- Management accounting is essentially forward looking

- Ongoing financial planning, monitoring, and budgetary control form its core

- It can be applied to the NHS so that managers can obtain the greatest value for money from their limited resources

- It is still developing in the context of the NHS

This technique was introduced in 1981 and updated in 1986. It has now been further updated to take into account the complexities of the internal market with the (long awaited) release of the new Capital Investment Manual. $^{8}$

Investment appraisal is, of course, a fundamental management accounting technique and enables such questions to be addressed as "Should we build a new ward for the care of the elderly?" or "Should we install a new boiler plant?" or "Should we purchase the latest piece of diagnostic equipment?" It also allows assessment of the likely changes in the NHS over a strategic planning period. As with budgetary capital, it is still evolving in the context of the NHS.

In many ways the impact of the NHS reforms has been to put the development of management accounting on hold. A clear agenda existed at the end of 1988. But the overall objective must be the development of a comprehensive management accounting structure which enables NHS managers to obtain the greatest value for money from their limited resources. The process is akin to completing a jigsaw puzzle. Undoubtedly the two new developments-the costing for contracting guidance and the Capital Investment Manual-are important pieces in the jigsaw. However, many pieces are still missing.

1 Royal Commission on the NHS. Management of financial resources in the NHS. London: HMSO, 1978. (Research paper No 2.)

2 Chartered Institute of Management Accountants. Management accountancyafficial terminology. London: CIMA, 1991.

3 Institute of Cost and Works Accountants. Terminology of cost accounting. London: ICWA, 1960.

4 Steering Group on Health Services Information (Chairman: Mrs E Korner) Department of Health and Social Security. 6th Report to the Secretary of State. London: HMSO, 1984.

5 Garbutt D. Making budgets work. London: Chartered Institute of Management Accountants, 1992

6 Henley D. Public sector accounting and financial control. 2nd ed. Wokingham: Van Nostrand Reinhold, 1986. 7 NHS Executive. Costing for contracting manual. Leeds: Department of Health,

8 NHS Executive. Capital investment manual. London: HMSO, 1994.

"Every Doctor is a Manager" is a conference being run by the $B M F, B M A$, and British Association of Medical Managers to explore the issues around doctors in management. It takes place on 16 February 1995 in London; details from the BMA Conference Unit, BMA House, Tavistock Square, London WC1H 9JR. Tel: 01713836605.

A book on the series, entitled Management for Doctors, will be published on 16 February to coincide with the conference; price UK $£ 12.95$; Overseas $£ 14.00$ (BMA members $£ 11.95 ; £ 13.00$ ) Order from the BMJ Publishing Group (tel $01713836185 / 6245$; fax 01713836662 ). 